\title{
Microplankton Composition and Spatial Distribution Along the West Antarctic Peninsula During the Late Summer of 2017
}

\author{
Ali Muzaffer Feyzioglu ${ }^{1, *}$ (D) Ersan Basar ${ }^{1}$, Ilknur Yildiz ${ }^{2}$, Burcu Ozsoy ${ }^{3}$ \\ ${ }^{1}$ Karadeniz Technical University, Faculty of Marine Sciences, 61530 Çamburnu, Trabzon, Turkey \\ ${ }^{2}$ Karadeniz Technical University, Institute of Marine Sciences and Technology, 61080 Ortahisar, Trabzon, Turkey \\ ${ }^{3}$ Istanbul Technical University, Maritime Faculty, Istanbul Turkey.
}

\section{Article History}

Received 28 October 2019

Accepted 14 August 2020

First Online 20 August 2020

\section{Corresponding Author}

Tel.: +905326608744

E-mail: mufeyzioglu@gmail.com

\section{Keywords}

Antarctica

West Antarctic Peninsula

Microplankton

Community Structure

Phytoplankton

\begin{abstract}
Microplankton is composed of organisms between 20 and $200 \mu \mathrm{m}$ in size (greatest axial linear dimension) and is a mixture of phytoplankton and zooplankton. It is an important component of the marine pelagic ecosystem not only as primary producers but also as consumers in the microbial loop. In the present paper, the results of microplankton species abundance and their community structure during the first Turkish Antarctic Expedition (TAE-1) at late Antarctic summer were given at four coastal stations along the west Antarctic Peninsula (WAP). According to these results, a total of 37 microplankton species were observed. Diatoms were the dominant group, followed by ciliates. The highest total microplankton cell concentrations were 18370 cells $\mathrm{I}^{-1}$ and 24350 cells $\mathrm{I}^{-1}$ at P4 and P2 sampling stations, respectively. Although the most common phytoplankton and ciliate species were Odontella weissflogii and Cymatocylis affinis, respectively, diversity indexes showed that no dominance of a species could be mentioned at any station. Additionally, we observed that the southern part of the WAP is significantly different from its northernmost part in microplankton abundance/composition
\end{abstract}

\section{Introduction}

Antarctica is the Earth's most southern continent. It covers Earth's South Pole. The area of Antarctica is $13.97 \times 10^{6} \mathrm{~km}^{2}$, making it the fifth largest of the seven continents (Stonehouse, 2002). Percent cover of coastal types around Antarctica are $95 \%$ of ice shelf (ice front $44 \%$, ice wall $38 \%$, ice stream/outlet glacier $13 \%$ ) and $5 \%$ of rock. It contains 91 percent $\left(30.1 \times 10^{6} \mathrm{~km}^{3}\right.$ of ice) of the estimated volume of all the ice on Earth (Swithinbank, 1993). Of all the world's continents, Antarctica is the coldest, the highest, and the least known.

The average monthly temperatures at sea level along the coast of Antarctica range from $-26.9^{\circ} \mathrm{C}$ to $-3.1^{\circ} \mathrm{C}$ during Antarctic winter and summer respectively
(Faure \& Mensing, 2010). Because of the mean air temperatures have increased approximately $2-3{ }^{\circ} \mathrm{C}$ along the Antarctic Peninsula in the course of the last half century, the region is known as the most rapidly warming places on Earth over the past 50 years (Moline et al., 2004; Turner et al., 2005). However, the model application showed that summer sea-surface temperatures (SSTs) at south of $60^{\circ} \mathrm{S}$ will be between 0.50 and $1.25^{\circ} \mathrm{C}$ warmer in 2100 than present (Flores et al., 2012). This increase, which causes the glacial melting, strongly influences overall phytoplankton productivity (Prézelin et al., 2000). The Antarctic coast is generally known as productive areas, but some areas are observed to be HNLC. Although the environmental conditions in the HNLC area are suitable for phytoplankton, phytoplankton biomass cannot increase 
at the desired level (Schloss et al., 2002). Various physical environmental factors such as vertical turbulence mixing, which modulates the light intensity and light penetration depth, can affect the phytoplankton growth and explain why low amount of biomass is observed (Schloss et al., 2002). Many researchers have determined that Antarctic phytoplankton growth is limited by light but not by nutrients (Hayes et al., 1984; Sommer, 1988). Beside these factors, micronutrients like iron also affects the distribution, biomass and productivity of the phytoplankton community (Ryan-Keogh et al., 2018).

Antarctic food web is usually described as short and Antarctic krill (Euphausia superba) is the key species in Antarctica. Many top-level consumers directly or indirectly use Antarctic krill as a food source (Laws, 1985). So, krill fulfils complex roles in ecosystem feedback loops through grazing and nutrient recycling (Atkinson et al., 2004). Diatoms-dominated spring phytoplankton populations are main food sources for krill (Moline et al., 2004). Phytoplankton can stay alive during the Antarctic winter about 6 months under limited light or almost no light condition (Wulff et al., 2008). Although they froze in the sea ice or buried in sediment, many of them survive and some of them are able to germinate years after (Davis, 1972; Zgurovskaya, 1977; Hollibaugh et al., 1981; Ligowski et al., 1992). Therefore, Antarctic diatoms rightfully constitute those microorganisms called extremophiles (Sterrenburg et al., 2007).

On the other hand, increases in seawater temperature can cause changes in phytoplankton community structure (Flores et al., 2012). Although Antarctic waters are rich in inorganic nutrients, it is considered as oligotrophic in terms of primary production for most of the year. Recent evidence showed, however, that an important part of primary production is carried out by pico- and nanoplankton rather than large diatoms. Pico- and nanophytoplankton generally comprise more than $30 \%$ and $50 \%$ of chlorophyll $a$ biomass, respectively (Azam et al., 1991; Hewes, 2009; Vanzan et al., 2015; Wright et al., 2009). This is important, because the krill which are regionally important key species, feeds on large phytoplankton, especially diatoms but not efficiently on pico- and nanoplanktonic groups. As indicated in many studies, changing in community composition from large diatoms to small size groups like flagellated cryptophytes may cause decreasing in the abundance of Antarctic krill (Moline et al., 2004; Mendes et al., 2018). Given the importance of diatoms, most studies have therefore focused on microplanktonic groups.

Antarctica is of great scientific interest not only for the valuable mineral resources and large deposits of oil and natural gas existing in its continental shelf but also because of its natural biological sources such as fishes and krill. Commercial harvesting of marine living resources in the Southern Ocean surrounding Antarctica began by hunting of seals during the late 1700 s and the commercial harvesting of krill during the 1970s (Herber, 2007). Antarctica, which is the world's most important natural laboratory, is a fragile and an increasingly vulnerable ecosystem of the world. Special international regulation is needed in Antarctica due to its biological, commercial and geopolitical importance. In this context, the Antarctic treaty that was firstly established in 1959 by 12 nations, was also signed by Turkey in 1995 . The Treaty has 50 member nations so far (Ozturk et al., 2014). Individual scientific studies have not been conducted by Turkish scientists and Turkey has not been performed any scientific activities in Antarctica until 2016. The first joint expedition on this continent was organized with the Ukrainian Antarctic Research Center during the 2016 Antarctic summer and supported by The Scientific and Technological Research Council of Turkey (TUBITAK) (Ozturk et al., 2017). Moreover, Turkey's first national Antarctic expedition (TAE-1) was held between February and March 2017 and was supported by the Ministry of Science and Industry. TAE-1 provided sampling opportunity of research along Antarctic Continental Shelf at various scientific areas.

Although previous studies have given historical information on the planktonic structure of Antarctic waters (Azam et al., 1991; Alder \& Boltovskoy, 1991; Schloss et al., 2002; Lange et al., 2007; Hewes, 2009; Garzio \& Steinberg, 2013), repetition of plankton studies is an obligation for a better understanding of environment. Thus, the main purpose of the present study is to give quantitative information on composition, community structure and biogeographic distribution of microplankton along the Antarctic Peninsula during the late summer of 2017 cruises of TAE-1.

\section{Material and Method}

Microplankton assemblages were sampled from March $5^{\text {th }}$ to $19^{\text {th }} 2017$ onboard of M/Y Australis. During the expedition, samples were taken from 4 sampling stations which were located along the Antarctic Peninsula and King George Island (Fig. 1). Stations P1 and P2 were located in the southernmost part of the Grandidier Channel. Station P3 was located in the coast of Cape Renard and station P4 was located at the southwest coast of the King George Island (Fig. 1 and Table 1). The distance between the northernmost station (P4) and the southernmost station (P1) is approximately 400 nautical miles. Samples were taken between the surface and 1-meter depth by using $55 \mu \mathrm{m}$ mesh size, $50-\mathrm{cm}$ diameter mouth of a Hensen type plankton net for 10-minute horizontal tows. Water volumes were calculated by using a Hydro-bios digital flow meter, which was attached to the mouth of the plankton net (Fraser \& Smith, 1968).

After each haul, the nets were carefully rinsed. The content of the collector at the lower end of the plankton net was fixed immediately after collection by adding $70 \%$ ethyl alcohol and kept inside of a $50 \mathrm{ml}$ glass bottle 
Table 1. Geographic locations and respective sampling dates for four sampling stations along the west Antarctica Peninsula

\begin{tabular}{|c|c|c|c|}
\hline Sampling Stations & \multicolumn{2}{|c|}{ Geographic locations } & Sampling dates \\
\hline P1 & $66033^{\prime} 54^{\prime \prime} \mathrm{S}$ & $66 \div 29^{\prime} 18^{\prime \prime} \mathrm{W}$ & $5^{\text {th }}$ March, 2017 \\
\hline P2 & $66023^{\prime} 03^{\prime \prime} \mathrm{S}$ & $65056^{\prime} 29^{\prime \prime} \mathrm{W}$ & $5^{\text {th }}$ March, 2017 \\
\hline P3 & $6500^{\prime} 52^{\prime \prime} \mathrm{S}$ & $64^{\circ} 00^{\prime} 16^{\prime \prime} \mathrm{W}$ & $8^{\text {th }}$ March, 2017 \\
\hline P4 & $62 \circ 12^{\prime} 59^{\prime \prime} \mathrm{S}$ & 59ㅇ $04^{\prime} 05^{\prime \prime} \mathrm{W}$ & $19^{\text {th }}$ March, 2017 \\
\hline
\end{tabular}

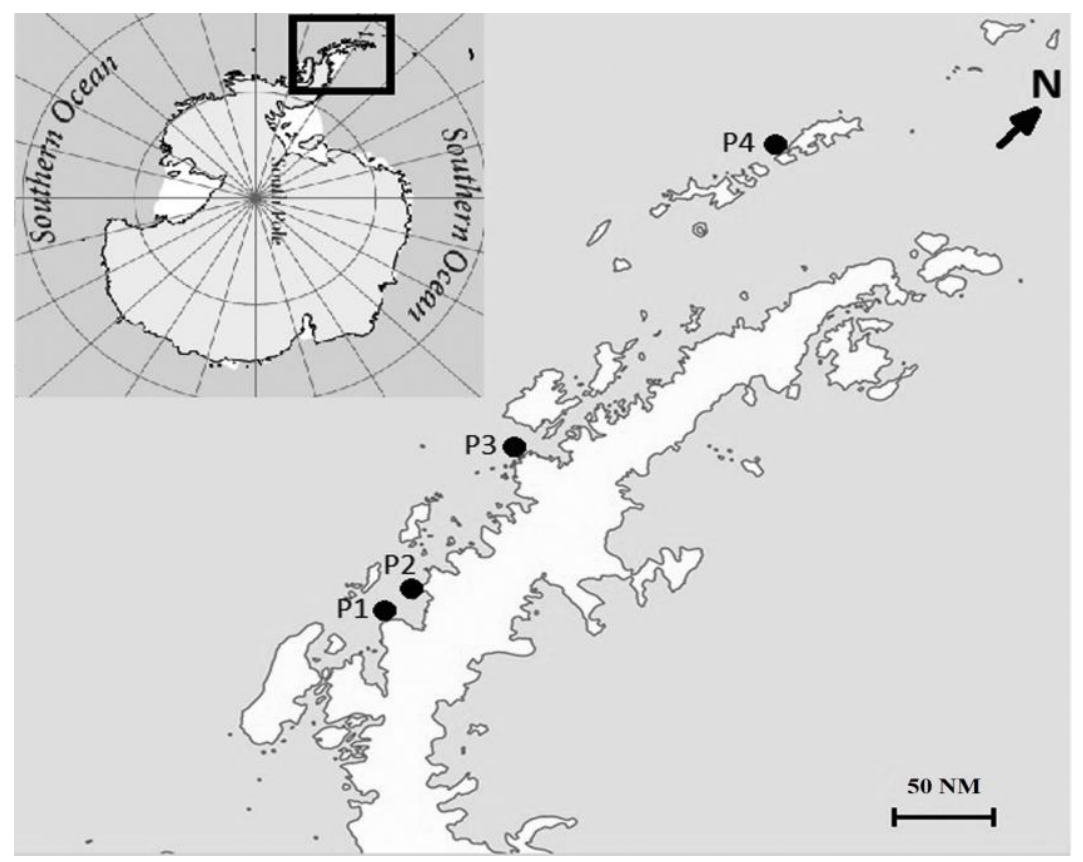

Figure 1. Sampling location.

in the dark until quantitative analysis (Alhaija et al., 2015). Before counting, $1 \mathrm{ml}$ of concentrated sample was taken and diluted to $40 \mathrm{ml}$. Planktonic cells in $1 \mathrm{ml}$ sample were counted under a Nikon E 600 light microscopy (equipped with phase contrast, dark field and fluorescence attachment) with 40x, 100x, 200x magnification using Sedgewick Rafter Counting Chamber. 400x magnification was used for identification of plankton species. After the microscope counts, cell numbers per 1 liter were calculated using dilution factor and volume of filtered sea water by plankton net (Harris et al., 2000). Pictures of planktonic organisms were taken with Microsystem Kameram 2 attachment and the Kameram Image Analysis System software was used for cell measurements. Sea Surface Temperature (SST) and chlorophyll-a data were obtained from NASA World View Earth Data WEB site (NASA, 2017). Bray-Curtis Similarity Index, MDS (Multidimensional Scaling) statistical analysis (Beals, 1984; Brogueira et al., 2007), Margalef Species Richness Index (d), Pielou's Evenness Index $\left(J^{\prime}\right)$ and Shannon Weaver Diversity Index $\left(\mathrm{H}^{\prime}\right)$ were applied for quantifying the compositional similarity between the sampling regions (Bandeira et al., 2013). All statistical analyses were done by using species number and abundance. PRIMER (Plymouth Routines in Multivariate Ecological Research, Plymouth Marine Laboratory, Plymouth, UK;) ver. 6 software was used for statistical data analysis (Clarke \& Gorley, 2006).

\section{Results}

According to satellite observations, SST ranged between $0.30-1.95{ }^{\circ} \mathrm{C}$ during the sampling period. Chlorophyll- $a(\mathrm{Chl}-a)$ is an important parameter for estimation of the biomass of autotrophic organisms and the satellite $\mathrm{Chl}-a$ concentrations spanned from $0.2 \mathrm{mg}$ $\mathrm{m}^{-3}$ to $0.83 \mathrm{mg} \mathrm{m}^{-3}$ at all sampling stations during the sampling period (Figure 2). Among the sampling stations, highest Chl- $a$ concentration was observed at P4 station, which was near the King George Island. In this station, Chl- $a$ concentration was between $\sim 0.80$ and $0.83 \mathrm{mg} \mathrm{m}^{-3}$. The lowest Chl- $a$ value was observed ( $\sim 0.2$ $\mathrm{mg} \mathrm{m}^{-3}$ ) at both stations $\mathrm{P} 1$ and $\mathrm{P} 2$. Although the satellite observation in our sampling area shows that $\mathrm{Chl}-a$ concentration was about $0.2 \mathrm{mg} \mathrm{m}^{-3}$, these concentrations reached to $15 \mathrm{mg} \mathrm{m}^{-3}$ at $200 \mathrm{~m}$ away from sampling sites at Adelaide Island's offshore areas, being 30 times higher than the $\mathrm{Chl}-a$ in the sampling stations (Figure 2)

A total of 37 microplankton species numbers belonging to diatom, dinoflagellate, cyanobacteria and ciliates were observed as $78.3 \%, 5.5 \%, 2.7 \%$, and $13.5 \%$ respectively. Diatoms were the dominant group followed by ciliates.

Odontella weissflogii (P1) and Corethron pennatum $(P 3, P 4)$ were the dominant diatom species. Among ciliates, Acanthostomella norvegica was the most 


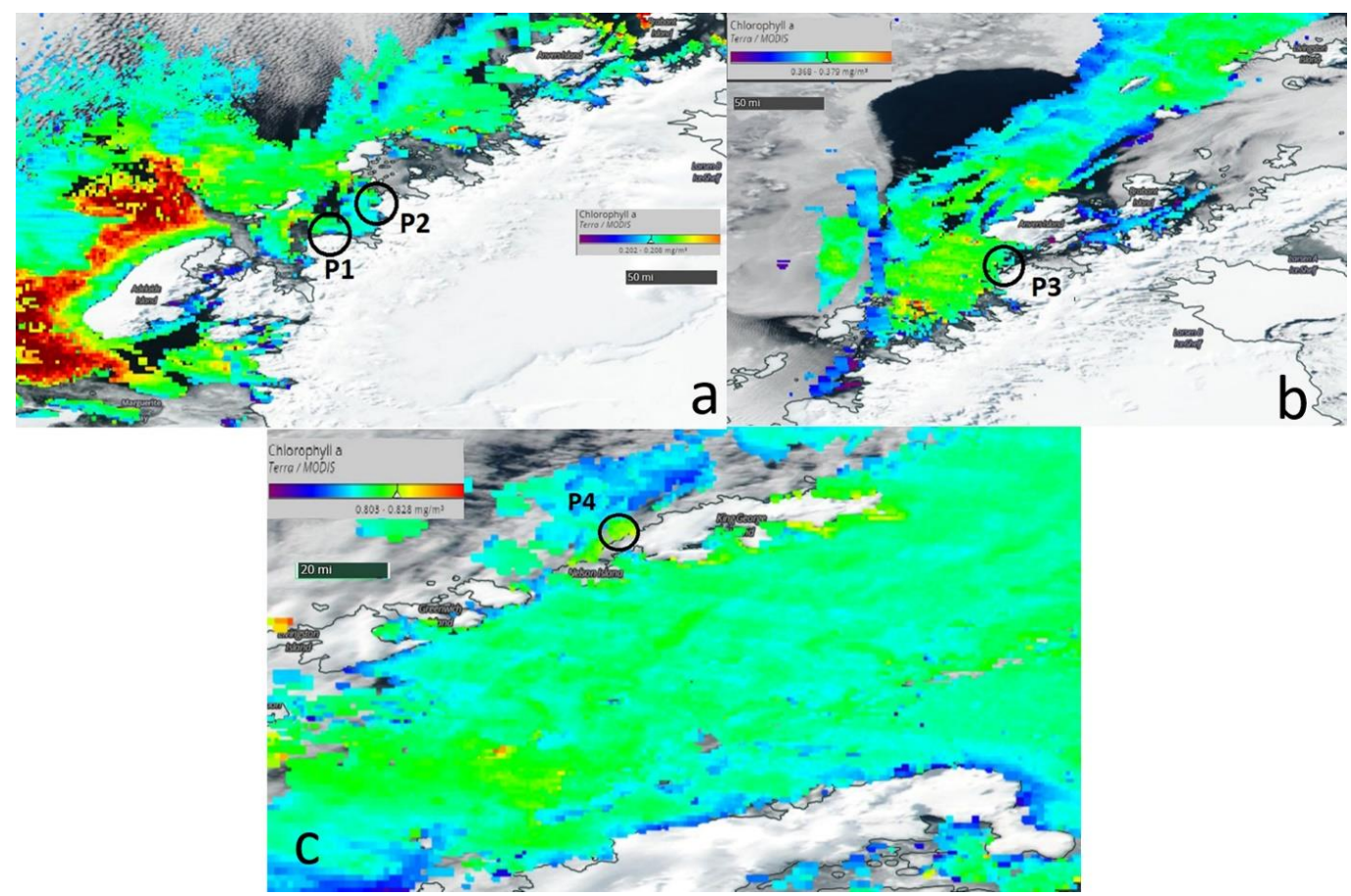

Figure 2. Satellite images of Chl- $a$ concentrations around the sampling periods (for sampling stations: (a) P1-P2: March $3^{\text {rd }}$, (b) P3: March $10^{\text {th }}$ and (c) P4: March 19th 2017$)$.

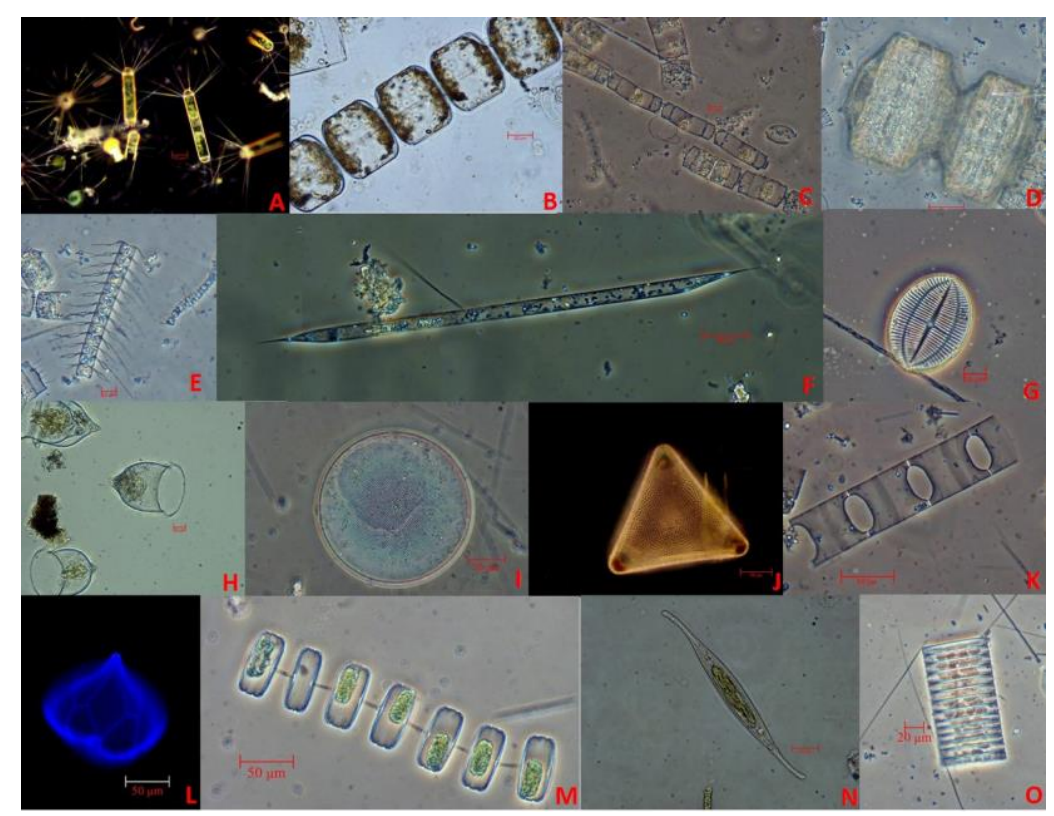

Figure 3. Microscope images of the most prominent microplankton species of west Antarctic Peninsula during March 2017 (late summer). A-Corethron pennatum B-Lauderia annulata C- Odontella weissflogii D- Coscinodiscus bouvet, E-Chaetoceros flexuosus F- Rhizosolenia polydactyla, G- Cocconeis britannica, H-Cymatocylis affinis, I-Coscinodiscus oculus-iridis, J-Trigonium arcticum, K- Eucampia antarctica, L- Protoperidinium depressum, M-Thalassiosira rotula, N- Gyrosigma fasciola, O- Fragilariopsis kerguelensis. Scale bar is $20 \mu \mathrm{m}$ for $\mathrm{B}, \mathrm{C}, \mathrm{E}, \mathrm{G}, \mathrm{H}, \mathrm{N}, \mathrm{O}$ and $50 \mu \mathrm{m}$ for $\mathrm{A}, \mathrm{D}, \mathrm{F}, \mathrm{I}, \mathrm{J}, \mathrm{K}, \mathrm{L}, \mathrm{M}$.

prominent species at P4 station during the sampling period. On the other hand, Coscinodiscus oculus-iridis, Fragilaria islandica and Thalassiosira rotula were observed in all sampling stations (Table 2, Figure 3).

The highest total microplankton cell concentrations were 18370 cells $~^{-1}$ and 24350 cells $\left.\right|^{-1}$ in P4 and P2 sampling stations, respectively. And the lowest cells number was 9440 cells $\mathrm{I}^{-1}$ in P3 station.
Although, the diatoms reached the highest cell numbers in P2 station, the maximum for microzooplankton was observed at station P4 (Figure 4). The dominant phytoplankton species was Odontella weissflogii, which reached 14329 cells I$^{-1}$ and 9200 cells I $^{-1}$ in station P2 and P1, respectively. While Acanthostomella norvegica belonging to the ciliate group was observed as dominant 
Table 2. A check-list of microplankton species and their level of abundance along the west Antarctic Peninsula (four sampling stations according to the Figure 1) during a late summer (March 2017)

\begin{tabular}{|c|c|c|c|c|}
\hline \multirow[b]{2}{*}{ Diatom } & \multicolumn{4}{|c|}{ Sampling stations } \\
\hline & P1 & $\mathrm{P} 2$ & P3 & P4 \\
\hline Centronella reicheltii & - & - & + & + \\
\hline Chaetoceros concavicornis & - & - & - & + \\
\hline Chaetoceros flexuosus & + & $*$ & - & - \\
\hline Chaetoceros hendeyi & + & $*$ & - & - \\
\hline Cocconeis britanica & - & - & + & + \\
\hline Cocconeis costatum & - & - & + & + \\
\hline Corethron pennatum & - & - & $* *$ & $* *$ \\
\hline Coscinodiscus bouvet & + & + & - & - \\
\hline Coscinodiscus radiatus & - & - & + & - \\
\hline Coscinodiscus oculus-iridis & + & + & + & + \\
\hline Cyclotella meneghiniana & - & - & + & - \\
\hline Entomoneis alata & - & - & - & + \\
\hline Eucampia antarctica & + & + & - & - \\
\hline Fragilaria capucina & - & - & + & + \\
\hline Fragilariopsis kerguelensis & + & + & + & + \\
\hline Gyrosigma fasciola & - & - & - & + \\
\hline Lauderia annulata & + & + & + & - \\
\hline Licmophora sp. & - & - & + & + \\
\hline Navicula sp. & - & - & + & - \\
\hline Odontella aurita & + & - & + & - \\
\hline Odontella weissflogii & $* *$ & $*$ & - & - \\
\hline Pleurosigma directum & - & - & + & + \\
\hline Proboscia inermis & - & - & - & + \\
\hline Pseudo-nitzschia lineola & + & + & + & - \\
\hline Rhizosolenia polydactyla & - & - & + & $*$ \\
\hline Rhizosolenia truncata & + & - & - & - \\
\hline Thalassiosira rotula & + & + & $*$ & + \\
\hline Trigonium arcticum & - & - & + & + \\
\hline \multicolumn{5}{|l|}{ Dinoflagellata } \\
\hline Protoperidinium depressum & - & + & + & - \\
\hline Protoperidinium sp. & + & - & + & - \\
\hline \multicolumn{5}{|l|}{ Cyanobacteria } \\
\hline Spirulina sp. & - & - & - & + \\
\hline \multicolumn{5}{|l|}{ Ciliophora } \\
\hline Acanthostomella norvegica & - & - & + & + \\
\hline Codonellopsis morchella & - & - & + & + \\
\hline Cymatocylis affinis & - & - & + & $* *$ \\
\hline Laackmanniella prolongata & - & - & + & - \\
\hline Protorhabdonella simplex & - & + & - & + \\
\hline
\end{tabular}

**: Predomimant (>5000 cells $\left.\left.\right|^{-1}\right)$

microzooplankton in the P4 station, reaching up to

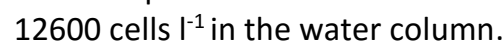

Margalef species richness index (d) and Shannon $\left(\mathrm{H}^{\prime}\right)$ were good indicators for understanding the species diversity and the structure of communities. High values indicate high species diversity in the sites/sampling region. Our data indicate that the $\mathrm{P} 3$ station has the highest species richness. However, the P2 station was identified as the region with the lowest species diversity. In general, the stations in northernmost part of west Antarctic Peninsula have low species diversity than the southernmost stations. Shannon-Weaver $\left(\mathrm{H}^{\prime}\right)$ species diversity index, which is used for the same purpose as Margalef index (d), similarly shows that stations at northern part of west Antarctica peninsula show low species diversity than the southernmost stations (Table 3). The index calculation results below 2.5 can indicate that the dominance of a species has begun. According to our index results dominance of a species can be mentioned in all station.

Pielou's evenness index ( $\left.J^{\prime}\right)$ gives the degree of equivalence in abundance of all species at the sample. As a result of the analysis, the station P4, close to the King George Island, showed higher evenness. On the other hand, P1 showed lower J' index than other sampling stations (Table 3 ).

The outputs of the Bray-Curtis similarity analysis are given in figure $5 \mathrm{~A}$ and $\mathrm{B}$. Two groups were identified by cluster analysis at 70\% (P1-P2) and 38\% (P3-P4) similarity level. Station P1 and P2 were differed 
Table 3. Number (S) and abundance in cells $\mathrm{I}^{-1}(\mathrm{~N})$ of taxa, Margalef's species richness (d), Shannon-Weaver $\left(\mathrm{H}^{\prime}\right)$ and Pielou's evenness index $\left(J^{\prime}\right)$ for the sampling stations across the west Antarctica Peninsula in late summer of 2017

\begin{tabular}{lccccc}
\hline Stations & $\mathrm{S}$ & $\mathrm{N}$ & $\mathrm{d}$ & $\mathrm{J}$ & $\mathrm{H}^{\prime}\left(\log _{\mathrm{e}}\right)$ \\
\hline P1 & 12 & 10260 & 1,586 & 0,1983 & 0,4927 \\
P2 & 11 & 18370 & 1,331 & 0,3334 & 0,7995 \\
P3 & 23 & 9440 & 3,211 & 0,3709 & 1,163 \\
P4 & 19 & 24350 & 2,308 & 0,4579 & 1,348 \\
\hline
\end{tabular}

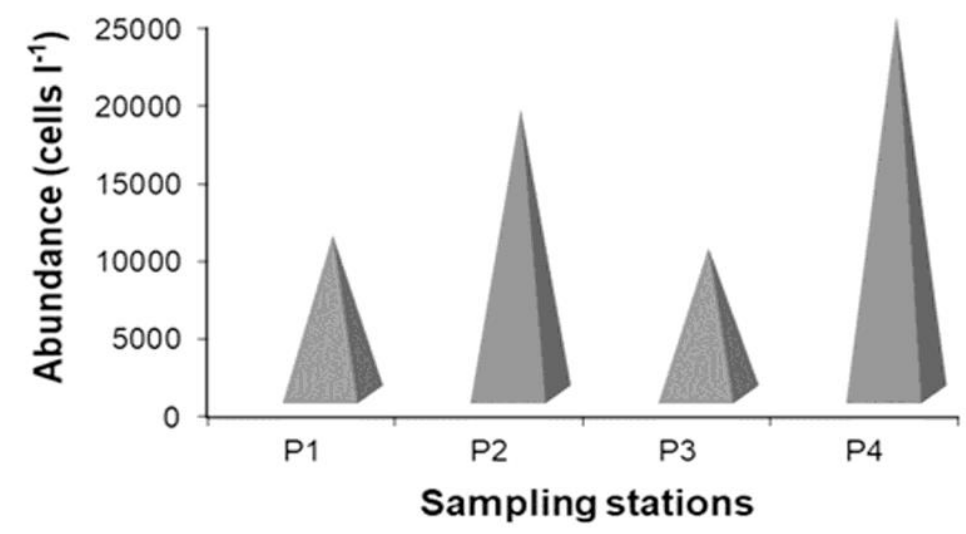

Figure 4. Total microplankton abundance (cells $\left.\right|^{-1}$ ) in the sampling stations.

significantly from station $\mathrm{P} 3$ and $\mathrm{P} 4$ and the similarity between those distinct groups (P1-P2 and P3-P4) was calculated as $1 \%$ (Figure $5 \mathrm{~B}$ ). Considering $50 \%$ similarity level of such groups, this led to the formation of three different microplanktonic areas along the Antarctic Peninsula (Figure 5A).

\section{Discussion}

This study showed that the microplankton compositions might have a dynamic structure along the west Antarctic Peninsula, during the late summer. There are many studies from different countries around the west Antarctic Peninsula due to its importance in pelagic ecosystem. For instance, phytoplankton studies showed that phytoplanktonic groups have been dominated by nanoplankton $(2-20 \mu \mathrm{m})$ and picoplankton $(0.2-2 \mu \mathrm{m})$ (Kopczynska, 2008). Nanoflagellates such as Cryptomonas sp. and Phaeocystis antarctica can cover approximately $83 \%$ of the total phytoplankton (Kang \& Lee, 1995). Kopczynska (2008) indicate that pico- and nanoplaktonic cell abundance can reach up to $4.0-$

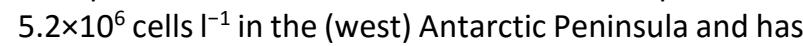
also showed that microplanktonic groups were secondary in abundance level. Although those small groups could be important also in late summer, we did not estimate the abundance of pico- and nanoplankton, since we used plankton net for sampling.

Another Antarctic study that was conducted at Neumayer Channel on five locations, in the vicinity of Vernadsky Research Base (Galindez Island) observed fifty phytoplankton species belonging to three taxonomic classes during the summer of 2016 and also, no significant difference was observed in phytoplankton species composition between the stations (Yılmaz et al., 2018). However, our results showed the great differences between the stations because of distinct geographic locations. These results showed that frequent sampling strategy was more important for determination of species diversity of certain areas. Diatom ratio to other planktonic groups was calculated as $78 \%$ in our studies. The relative abundance of diatoms presented here was similar to the one observed by Yılmaz et al. (2018).

Phytoplankton biomass is typically low in King George Island when compared to other Antarctic shelf environments. For instance, diatoms have been usually found in the west Antarctic Peninsula as typical bloomforming species (Schloss et al., 2014). Lange et al. (2007) also showed that diversity of phytoplankton population was high and the main group was diatom during the summer 2002-2003 in Admiralty Bay at King George Island. The centric diatom Corethron pennatum and several species of the pennate diatom genus Fragilariopsis were dominant. Although, the observed microplankton species numbers were recorded as 113 , maximum cells abundance were not more than $10^{3}$ cells $\mathrm{I}^{-1}$ in that area (Lange et al., 2007).

Although the species diversity has been high in some studies mentioned above, Kang and Lee (1995) showed that the phytoplankton species was not only low but also dominated by 5 or 6 species that covered more than $95 \%$ of the total phytoplankton, as observed at WAP in our work. The species diversity was relatively 

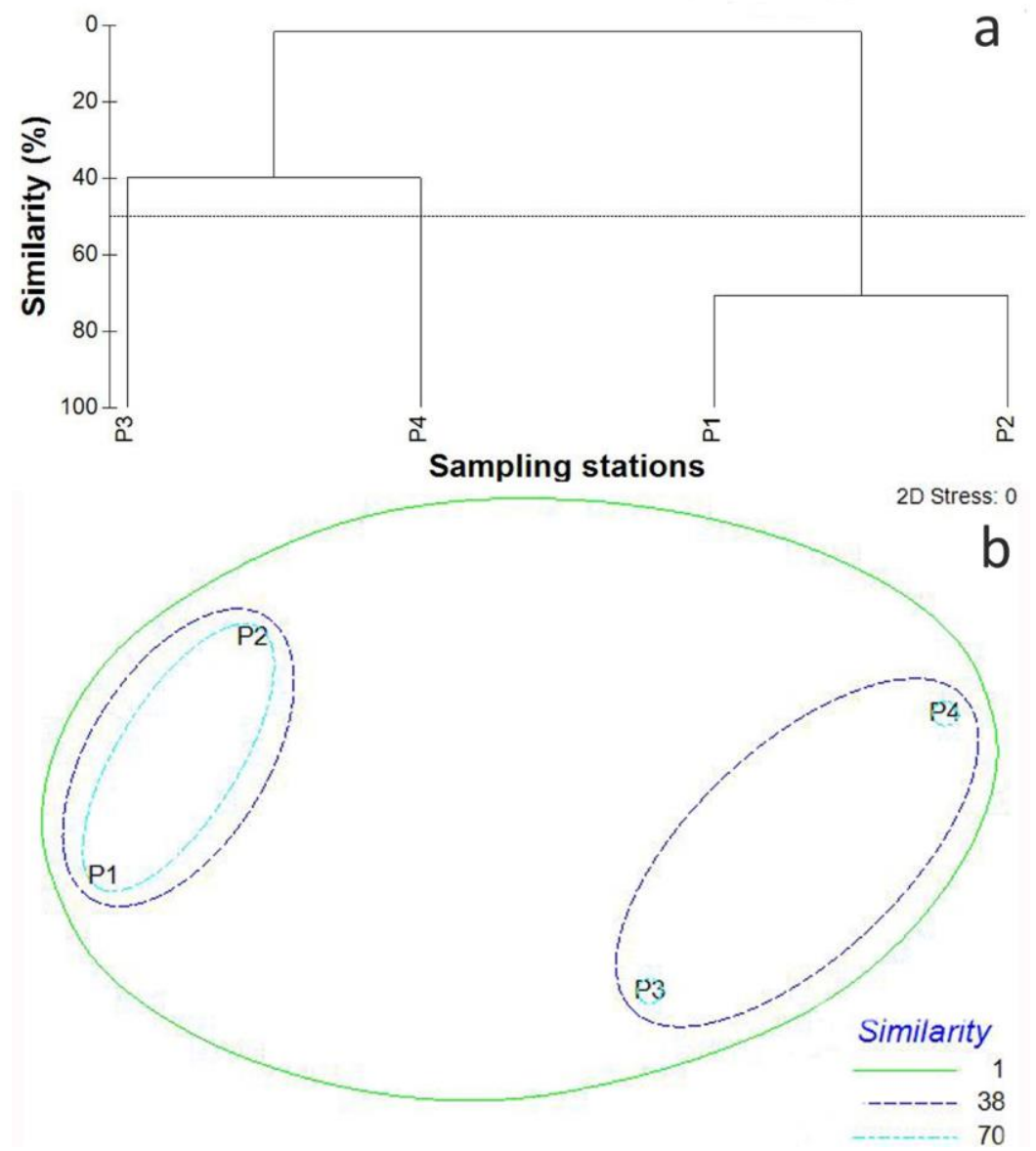

Figure 5. Groups of samples obtained from similarity matrix based on microplankton abundance data. Represented as: (a) Cluster analysis (CA) dendrogram and station groups according to $50 \%$ similarity level of microplanktonic biota. (b) MDS: Station groups are indicated in agreement with groups from the CA dendrogram according to $1 \%$ (green ellipse), 38\% (dashed dark blue ellipse) and $70 \%$ (dash-dot, pale blue ellipse).

low in our stations, but the abundance values of species are higher when compared with Lange et al. (2007) and Yilmaz et al. (2018). In Lange et al. (2007) study the cells number for dominant species was $10^{4}$ cells $\mathrm{I}^{-1}$. Other studies have also indicated that Odontella weissflogii and Corethron pennatum can characterize the typical species of Antarctic summer phytoplankton community (Detoni et al., 2015; Yılmaz et al., 2018). Almost the same species were observed at these previous studies conducted in similar summer periods. According to our observation, Odontella weissflogii and Corethron pennatum were the most abundant species across those sites of west Antarctic Peninsula (WAP) during 2017 late summer.

Microzooplankton abundance and composition have been showed some regional differences across the wAP. The exclusive high ciliate abundance in the P4 station was an example of this kind of regional variabilities. This finding could be related to pico- and nanoplankton abundance levels. Mendes et al. (2018) showed that the shift from large diatoms to small flagellates could stimulate the microbial loop dynamics and affect negatively the krill abundance in Antarctic food webs. For instance, even though heterotrophic dinoflagellates were the most significant grazers in oceanic zone of Amundsen Sea, ciliates co-dominated with them in the Sea Ice Zone at the same area (Yang et al., 2016). Also, athecate heterotrophic dinoflagellates and flagellates were the dominant groups in midsummer of 2010, while these kinds of dinoflagellates and aloricate ciliates predominated in 2011 midsummer. Whereas the tintinnids were a less important group along the Antarctic Peninsula during those same sampling periods (Garzio \& Steinberg, 2013). Alder and Boltovskoy (1991) recorded the highest absolute counts for the silicoflagellates (7777 cells ${ }^{-1}$,

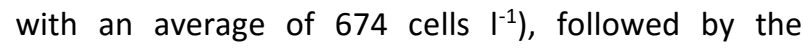
dinoflagellates (maximum: 1312 cells $\mathrm{l}^{-1}$, average: 109 cells $\mathrm{I}^{-1}$ ) and the tintinnids (maximum: 589 cells $\mathrm{I}^{-1}$,

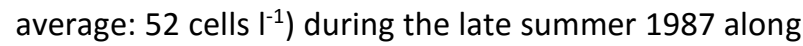
the WAP, whose (some) locations were covered by our study area. When our findings were compared with ones of previous studies, the cell numbers showed similarity and differences according to sampling sites and seasons. In studies that occupied offshore stations, the number of cells that were determined in our work, have counted high cell abundance. Alder and Boltovskoy (1991)'s results of microzooplankton in 1989 were similar to our study. Moreover, Alder and Boltovskoy (1991)'s study, which was conducted 30 years ago for the exact same period as our research, showed that the distribution of Cymatocylis affinis was similarly observed 
in our work. However, this distribution was not mentioned in other studies. It was also observed that in March 1987 (Alder \& Boltovskoy 1991) three geographical regions were defined according to the microplankton structure as in our study.

Changing climatic and ecological conditions can affect the food web dynamics starting from plankton up to the top predators through all marine Antarctic pelagic ecosystems. Consequently, time-series dataset will be very important for understanding the changes in these fragile ecosystems. When compare our study period with data obtain from the previous study our limited data that belong to the limited area in this study provide the evidence that microplanktonic community were affected by changing environmental conditions during the last two decades. For the better understanding of Antarctic marine ecosystem's future, more detailed studies, which are supported by inter-governmental foundations, are needed.

\section{Acknowledgement}

This study was carried under the auspices of Turkish Republic Presidency, supported by the Ministry of Science Industry and Technology (Number: TAE 1), and the project was coordinated by Istanbul Technical University (ITU) Polar Research Center (PolReC). We acknowledge the use of imagery from the NASA Worldview application (https://worldview.earth data.nasa.gov/) operated by the NASA/Goddard Space Flight Center Earth Science Data and Information System (ESDIS) project.

\section{References}

Alder, V.A., \& Boltovskoy, D. (1991). Microplanktonic Distributional Patterns West of The Antarctic Peninsula, with Special Emphasis on The Tintinnids. Polar Biology, 11(2), 103-112. https://doi.org/10.1007/BF00234272

Alhaija, A, R., Jimenez, C., Mortier, L., \& Lange, M. (2015). Implementation of the Continuous Plankton Recorder (CPR) in the Mediterranean Sea. PERSEUS Project ISBN no: 978-960-9798-16-7, $48 \mathrm{p}$.

Atkinson, A., Siegel, V., Pakhomoy, E., \& Rothery, P. (2004). Longterm Decline in Krill Stock and Increase in Salps within the Southern Ocean. Nature, 432, 100-103. https://doi.org/10.1038/nature02996

Azam, F., Smith, D.C., \& Hollibaugh, J.T. (1991). The Role of The Microbial Loop in Antarctic Pelagic Ecosystems. Polar Research, 10 ,

239-244. https://doi.org/10.3402/polar.v10i1.6742

Bandeira, B., Jamet, J.-L., Jamet, D., \& Ginoux, J.M. (2013). Mathematical Convergences of Biodiversity Indices. Ecological Indicators, 29, 522-528. https://doi.org/10.1016/j.ecolind.2013.01.028

Beals, E. W. (1984). Bray-Curtis Ordination: An Effective Strategy for Analysis of Multivariate Ecological Data. Advances in Ecological Research, 14, 1-55. https://doi.org/10.1016/S0065-2504(08)60168-3

Brogueira, M. J., Oliveira, M. do R., \& Cabeçadas, G. (2007). Phytoplankton community structure defined by key environmental variables in Tagus estuary, Portugal. Marine Environmental Research, 64(5), 616-628. https://doi.org/10.1016/j.marenvres.2007.06.007

Clarke, K.R., \& Gorley, R.N. (2006). Primerv6: User Manual/Tutorial, Primer-E, Plymouth, $190 \mathrm{pp}$.

Davis, J.S. (1972). Survival Records in The Algae, and The Survival Role of Certain Algae Pigments, Fat, and Mucilaginous Subseances. The Biologist, 54(2), 52-93.

Detoni, A.M.S., de Souza, M.S., Garcia, C.A.E., Tavano, V.M., \& Mata, M.M. (2015). Environmental Conditions during Phytoplankton Blooms in the Vicinity of James Ross Island, East of the Antarctic Peninsula. Polar Biology, 38(8), 1111-1127. https://doi:10.1007/s00300-0151670-7

Faure, G., \& Mensing, T.M. 2010. The Transantarctic Mountains Rocks, Ice, Meteorites and Water. Springer Science \& Business Media, 600 pp.

Flores, H., Atkinson, A., Kawaguchi, S., Krafft, B.A., Milinevsky, G., Nicol, S., Reiss, C., Tarling, G.A., Werner, R., Bravo Rebolledo, E., Cirelli, V., Cuzin-Roudy, J., Fielding, S., Groeneveld, J.J., Haraldsson, M., Lombana, A., Marschoff, E., Meyer, B., Pakhomov, E.A., Rombolá, E., Schmidt, K., Siegel, V., Teschke, M., Tonkes, H., Toullec, J.Y., Trathan, P.N., Tremblay, N., Van de Putte, A.P., van Franeker, J.A., \& Werner, T. (2012). Impact of Climate Change on Antarctic Krill. Marine Ecology Progress Series, Inter-Research, 458, 1-19. https://doi: 10.3354/meps09831

Fraser, J.H., \& Smith, P.H. (1968). Filtration Performance. In D.J. Tranter (Eds.), Zooplankton Sampling Monographs on Oceanic Methodology (pp.26-56). No. 2. Print in Paris: UNESCO.

Garzio, L.M., \& Steinberg, D.K. (2013). Microzooplankton Community Composition along the Western Antarctic Peninsula. Deep Sea Research Part I Oceanographic Research Papers, 77:36-49. https://doi: 10.1016/j.dsr.2013.03.001

Harris, R., Wiebe, P., Lenz, J., Skjoldal, H.R., \& Huntley, M. (2000). ICES Zooplankton Methodology Manual. London, UK: Academic Press, 684 pp.

Hayes, P.K., Whitaker, T.M., \& Fogg, G.R. (1984). The Distribution and Nutrient Status of Phytoplankton in The Southern Ocean Between $20^{\circ}$ and $70^{\circ}$ W. Polar Biology, 3(3), 153-165. https://doi: 10.1007/BF00442647

Herber, B.P. (2007). Protecting The Antarctic Commons: Problems of Economic Efficiency. Published by the Udall Center for Studies in Public Policy, p.73. The University of Arizona

Hewes, C.D. (2009). Cell Size of Antarctic Phytoplankton as A Biogeochemical Condition. Antarctic Science, 21(5), 457470. https://doi:10.1017/S0954102009990125

Hollibaugh, T.J., Seibert, D.L.R., \& Thomas, W.H. (1981). Observations on The Survival and Germination of Resting Spores of Three Chaetoceras (Bacillariphyceae) Species. Journal of Phycology, 17(1), 1-9. https://doi.org/10.1111/j.1529-8817.1981.tb00812.x

Kang, S.H., \& Lee, S. (1995). Antarctic Phytoplankton Assemblage in The Western Bransfield Strait Region, February 1993: Composition, Biomass, and Mesoscale Distributions. Marine Ecology Progress Series, 129(1-3), 253-267. https://doi:10.3354/meps129253

Kopczynska, E.E. (2008). Phytoplankton Variability in Admiralty Bay, King George Island, South Shetland Islands: Six Years of Monitoring. Polish Polar Research, 292 (2), 117-139. 
Lange, P.K., Tenenbaum, D.R., De Santis Braga, E., \& Campos, L.S. (2007). Microphytoplankton Assemblages in Shallow Waters of Admiralty Bay (King George Island, Antarctica) During The Summer 2002-2003. Polar Biology, 30(11), 1483-1492. https://doi: 10.1007/s00300-007-0309-8

Laws, R.M. (1985). The Ecology of the Southern Ocean. American Scientist, 73, 26-40.

Ligowski, R., Godlewski, M.M., \& Lukowski, A. (1992). Sea Ice Diatoms and Ice Edge Planktonic Diatoms at The Northern Limit of the Weddell Sea Pack Ice. Proceedings of the NIPR Symposium on Polar Biology, 5, 9-20.

Mendes, C.R.B., Tavano, V.M., Dotto, T.S., Kerr, R., De Souza, M.S., Garcia, C.A.E., \& Secchi, E.R. (2018). New Insights on the Dominance of Cryptophytes in Antarctic Coastal Waters: A Case Study in Gerlache Strait. Deep Sea Research Part II Topical Studies in Oceanography, 149, 161-170. https://doi.org/10.1016/j.dsr2.2017.02.010

Moline, M.A., Claustre, H., Frazer, T.K., Schofield, O., \& Vernet, M. (2004). Alteration of the Food Web along The Antarctic Peninsula in Response to a Regional Warming Trend. Global Change Biology, 10(12), 1973-1980. https://doi: 10.1111/j.1365-2486.2004.00825.x.

Ozturk, B., Fach, B., Cicek, O.B., Husrevoglu, S., Salihoglu, B., Ergul, H.A., Aktas, S., Cotuk, B., Cifci, G., \& Ozturk, A.A. (2014). Towards the Turkish Antarctic Science Programme. Journal of the Black Sea / Mediterranean Environment, 20(1), 92-95.

Ozturk, B., Tonay, M.A., Oz, M.I., Yılmaz, I.N., Ergul, H.A., \& Ozturk, A.A. (2017). Sightings of Cetaceans in the Western Antarctic Peninsula during the First Joint Turkish- Ukrainian Antarctic Research Expedition, 2016. Turkish Journal of Zoology, 41, 955-961. https://doi:10.3906/zoo-1611-48

Pielou, E.C. (1960). A Single Mechanism to Account for Regular, Random and Aggregated Populations. Journal of Ecology, 48(3), 574-584. https://doi:10.2307/2257334

Prezelin, B.B., Hofmann, E.E., Mengelt, C., \& Klinck, J.M. (2000). The Linkage Between Upper Circumpolar Deep Water (UCDW) and Phytoplankton Assemblages on The West Antarctic Peninsula Continental Shelf. Journal of Marine Research, 58(2), 165-202. https://doi: 10.1357/002224000321511133

Ryan-Keogh, T.J., Thomalla, S.J., Mtshali, T.N., van Horsten, N.R., \& Little, H.J. (2018). Seasonal Development of Iron Limitation in The Sub-Antarctic Zone. Biogeosciences, 15(14), 4647-4660. https://doi:10.5194/bg-15-46472018

Schloss, I.R, Ferreyra, G.A., \& Ruiz Pino D. (2002). Phytoplankton Biomass in Antarctic Shelf Zones: A Conceptual Model Based on Potter Cove, King George Island. Journal of Marine Systems, 36(3-4), 129-143. https://doi:10.1016/S0924-7963(02)00183-5

Schloss, I.R., Wasilowska, A., Dumont, D., Almandoz, G.O., Hernando, M.P., Michaud-Tremblay, C.A., Saravia, L., Rzepecki, M., Monien, P., Monien, D., Kopczyńska, E.E., Bers, A.V., \& Ferreyra, G.A. (2014). On The Phytoplankton Bloom in Coastal Waters of Southern King
George Island (Antarctica) in January 2010: An exceptional feature?. Limnology and Oceanography, 59 (1), 195-210. https://doi:10.4319/lo.2014.59.1.0195

Sommer, U. (1988). The Species Composition of Antarctic Phytoplankton Interpreted in Terms of Tilman's Competition Theory. Oecologia, 77(4), 464-467. https://doi:10.1007/BF00377261

Sterrenburg, F., Gordon, R., Tiffany, M.A., \& Nagy, S.S. (2007). Diatoms: Living in a Constructal Environment. In: J. Seckback (Eds.): Cellular Origin, Life in Extreme Habitats and Astrobiology Algae and Cyanobacteria in Extreme Environments 11 (pp. 141-172). The Netherlands: Springer, $812 \mathrm{pp}$.

Stonehouse, B. (2002). Encyclopedia of Antarctica and the Southern Oceans. England: Chichester: John Wiley \& Sons, Ltd., pp 391.

Swithinbank, C. (1993). Satellite Image Atlas of Glaciers of the World Antarctica, U.S. Geological Survey Professional Paper 1386-B. Washington, pp.131.

Turner, J., Colwell, R.R., Marshall, G.J., Lachlan-Cope, T.A., Carleton, A.M., Jones, P.D., Lagun, V., Reid, P.A., \& lagovkinas, S. (2005). Antarctic Climate Change During The Last 50 Years. International Journal of Climatology, 25, 279-294. https://doi.org/10.1002/joc.1130

Vanzan, M., Barrera-Alba, J.J., Tenório, M.M.B., \& Tenenbaum, D.R. (2015). Picoplankton and Nanoplankton Variability in an Antarctic Shallow Coastal Zone (Admiralty Bay) During The Austral Summer of 2010/2011. Polar Biology, 38(8), 1267-1284. https://doi:10.1007/s00300-015$1692-1$

Wright, S.W., Ishikawa, A., Marchant, H.J., Davidson, A.T., Enden, R.L., \& Nash, G.V. (2009). Composition and Significance of Picophytoplankton in Antarctic Waters. Polar Biology, 32(5), 797-808. https://doi.org/10.1007/s00300-009-0582-9

Wulff, A., Zacher, K., Hanelt, D., Al-Handal, A., \& Wiencke, C. (2008). UV Radiation - a Threat to Antarctic Benthic Marine Diatoms?. Antarctic Science, 20(1), 13-20. https://doi:10.1017/S0954102007000739

Yang E.J., Jiang Y. \& Lee S. 2016. Microzooplankton herbivory and community structure in the Amundsen Sea. Antarctica Deep-Sea Research Part II 123, 58-68.

Yılmaz, I.N, Ergul, H.A., Mavruk, S., Taş, S., Aker, H.V., Yıldız, M., \& Ozturk, B. (2018). Coastal Plankton Assemblages in the Vicinity of Galindez Island and Neumayer Channel (Western Antarctic Peninsula) during the First Joint Turkish -Ukrainian Antarctic Research Expedition. Turkish Journal of Fisheries and Aquatic Sciences, 18(4), 577-584. https://doi:10.4194/1303-2712-v18_4_09

Zgurovskaya, L.N. (1977). Effect of Addition of Nutrients on Growth of Spores and Division of Plankronic Algae from Bottom Sediments. Okeanologiya, 17(1), 119-122 